\title{
REFERENCES
}

Aschkenasy-Lelu, P. \& Aschkenasy, A. (1957). Archs Sci. physiol. rx, Iz5.

Aschkenasy-Lelu, P. \& Aschkenasy, A. (1959). Wld Rev. Nutr. Diet. I, 29.

Beaton, G. H. (г 96т). Fedn Proc. Fedn Am. Socs exp. Biol. 20, Suppl. 7, p. 196.

Brown, J. B. (1957). F. Endocr. 16, 202.

Campbell, R. M., Innes, I. R. \& Kosterlitz, H. W. (I953). F. Endocr. 9, 68.

Doe, R. P., Zinneman, H. H., Flink, E. B. \& Ulstrom, R. A. (1960). F. clin. Endocr. Metab. 20, 1484,

Frandsen, V. A. (1963). The Excretion of Oestriol in Normal ITuman Pregnancy. Copenhagen:

Munksgaard.

Fry, E. G., Miller, M. \& Long, C. N. H. (1942). Endocrinology 3o, Srozg.

Gemzell, C. A. (1952). Acta endocr., Copenh. II, 221.

Gemzell, C. A. (1953). \%. clin. Endocr. r3, 898 .

Gillman, J. \& Gilbert, C. (1958). Br. med. F. i, 57.

Goodlad, G. A. J. \& Munro, H. N. (1959). Biochem. F. 73, 343.

Herring, P. T. (x920). Br. med. 7. ii, 886 .

Hervey, G. R. \& Hervey, E. (I 964). F. Endocr. 3o, vii.

Hunscher, H. A., Hummell, F. C., Erickson, B. N. \& Macy, I. G. (1935). F. Nutr. ro, 579.

Hytten, F. E. (1964). Proc. int. Congr. Nutr. vi. Edinburgh, p. 59.

Hytten, F. E. \& Leitch, I. (I964). The Physiology of Human Pregnancy. Oxford: Blackwell Scientific Publications.

Laroche, G. \& Trémolières, J. (I948). Annls Endocr. 9, 7 I.

Leathem, J. H. (1966). 7. Anim. Sci. 25, 68S.

McGanity, W. J., Cannon, R. O., Bridgforth, E. B., Martin, M. P., Densen, P. M., Newbill, J. A., McCellan, G. S., Christic, A., Peterson, J. C. \& Darby, W. J. (1954). Am. Э. Obstet. Gynec. $67,50 \mathrm{I}$

Munro, H. N. (1956). Scot. med. F. i, 285.

Naismith, D. J. (1966). Metabolism 15, 582 .

Scow, R. O., Chernick, S. S. \& Brinley, M. S. (1964). Am. F. Physiol. 2o6, 796.

Sprague, R. G., Mason, H. L. \& Power, M. H. (195I). Recent Prog. Horm. Res. 6, 3 I 5.

Taggart, N. (rg6r). Proc. Nutr. Soc. 20, xxx.

Thomson, A. M. (1959). Br. F. Nutr, 13, 509.

\section{Pathological and experimental studies of intrauterine malnutrition}

\section{By J. S. Wigglesworth, Institute of Child Health, Hammersmith Hospital, Wr2}

It has long been recognized that there may be considerable variations in birth weight of individual foetuses within litters of animals such as pigs, mice and rabbits. Several workers have investigated the factors responsible for variations in birth weight with litter size and with the position of runts within the uterus (Eckstein, McKeown \& Record, 1955; McLaren \& Michie, I960). As there is not normally any suggestion that individuals within a litter were conceived at different times the differences are accepted as reflecting variations in intrauterine growth rate.

Only in the last 20 years, however, has it become generally recognized that similar variation in intrauterine growth rate may occur in man, who has an average litter size only fractionally above one. Delayed recognition of variations in intrauterine growth rate in man (particularly intrauterine growth retardation) has largely been due to lack of objective evidence of time of conception. As birth weight was the only entirely objective parameter of maturity available any baby of $2.5 \mathrm{~kg}$ birth weight or less was until recently by definition a premature baby. There was 
always muddled thinking on this score as nobody suggested that the overgrown babies of diabetic women were necessarily post-mature.

The realization that man does not differ from other mammals in respect of variations in foetal growth rate, and the recognition of the hazards associated with intrauterine growth failure, have prompted attempts to establish normal intrauterine growth curves for different populations. Attempts have been made also to fix limits for normality, lower limits in particular, so as to define the group of babies at risk to the complications associated with inadequate foetal growth.

Two main methods have been used in plotting such curves: (I) the establishment of a mean curve and curves at one and two standard deviations above and below the mean and (2) the plotting of such curves on the percentile notation used by paediatricians for following height, weight and head circumference growth in children.

The advantage of the percentile notation is that it can be used in cases where there is uneven distribution about the mean. No really adequate intrauterine growth chart yet exists as boys at term weigh significantly more than girls and nobody has yet produced sets of curves with mean and standard deviation plotted separately for boys and girls.

On the curves that are available two different definitions of small-for-dates (SFD) babies are in common use. The definition used by pathologists, two standard deviations or more below the mean (Gruenwald, I963), includes the babies who show the more obvious pathological features. The inclusive definition favoured by paediatricians takes in all babies below the roth percentile so as not to miss any of those who may suffer from complications of foetal growth retardation such as hypoglycaemia.

Further comments on the human situation will refer mainly to babies of more than two standard deviations below the mean birth weight, which for babies born in the United Kingdom means a weight of $2.5 \mathrm{~kg}$ or less at term. Length and head circumference in SFD babies tend to be less retarded than body-weight (Gruenwald, 1963 ), so that the typical SFD baby is long and thin with a rather large cranium. Clinically he may be distinguished from his premature counterpart also by his advanced reflex development (Robinson \& Tizard, I966). The SFD baby who comes to necropsy shows lack of soft tissues, particularly subcutaneous fat. Organs such as liver, lungs and thymus are smaller than those of a truly premature infant of similar weight; the heart weight is rather greater than expected for the birth weight and the brain weight markedly so.

The change in relative weights of the organs results in an increased ratio of brain weight to liver weight from the normal of about $3: 1$ up to as high as $6: 1$ in babies who are markedly small for dates (Dawkins, 1964). The gyral convolutional pattern of the brain shows the development expected for the gestation as do the renal glomeruli and pulmonary alveoli on histological study. Appearance of ossification centres within the epiphyses may, however, be delayed in SFD babies, rendering antenatal X-ray diagnosis of maturity inaccurate (Scott \& Usher, 1964). The external appearance and organ weight variations of a SFD baby are similar to those of a baby who has been undernourished postnatally, arousing the suspicion that 
many SFD babies have suffered from a process of intrauterine malnutrition as implied in McBurney's (1947) description of them as 'under-nourished term infants'. The quantitative histological studies of Naeye ( $9_{96}{ }_{5} a$ ) have shown that the reduction in organ size is due primarily to a reduction in cytoplasmic mass rather than to a reduction in cell number, both in the malnourished looking SFD baby and in the baby undernourished postnatally.

The importance of recognizing these babies is shown by the high perinatal mortality of SFD babies found in the National Perinatal Mortality Survey in $195^{8}$ (Butler, 1965). The SFD baby is at increased risk to asphyxia during delivery and to pneumonia and massive pulmonary haemorrhage during the neonatal period. 'The occurrence of neonatal hypoglycaemia was not recognized in $195^{8}$ so there are no figures relating to deaths from this cause. The small livers and low liver glycogen levels of SFD babies (Shelley, r 964) may be sufficient to account for the occurrence of neonatal hypoglycaemia, but there is some evidence (Schiff, I968) that pancreatic insulin output may remain inappropriately high after hypoglycaemia has developed. The brains of babies dying after prolonged hypoglycaemia show widespread severe nerve cell damage with pyknosis or fragmentation of nuclear chromatin in nerve cells throughout the brain and chromatolysis and swelling of cytoplasm of some of the large neurones (Anderson, Milner \& Strich, 1966).

A separate group of SFD babies recently described (Naeye, $1965 b$ ) includes babies born to mothers infected with rubella in early pregnancy, and those with some forms of congenital malformation. These infants do not show the features described above as typical of intrauterine malnutrition but have marked reduction in the weight of all organs, including the brain. Quantitative histological study reveals in these babies a reduction in cell population of different organs. Naeye postulates that an influence causing temporary impairment of mitotic activity early in pregnancy may induce malformation within one or more actively differentiating organs and at the same time limit the growth potential of all organs by suppressing a vital generation of cell divisions. Clinicians are well aware that many congenitally malformed babies are of low birth weight for gestation, and teratologists often find that foetal growth retardation is produced in experimental animals more readily than overt malformations.

It is not possible fully to separate mechanisms which may cause foetal growth retardation from those normally responsible for control of foctal growth. Many studies in both man and experimental animals have indicated that normal birth weight is determined primarily by maternal environment rather than genetic factors. The work of McKeown \& Record (1953) indicated that the flattening out of the human foetal growth curve towards the end of pregnancy was due to increasing maternal constraint on foetal growth. If foetal growth is constrained from an earlier stage of pregnancy than normal the baby will be small for dates.

It is possible in animals such as the sheep to reduce birth weight significantly by restricting maternal food intake in the last 6 weeks of pregnancy (Hammond, I96r). In such cases the growth-retarded lamb presents similar features to those seen in the SFD baby. However, foetal nutrition is not necessarily directly related 
to maternal food intake during pregnancy, and some form of limitation on maternal foetal transfer in late pregnancy might well result in foetal starvation despite adequate maternal nutrition.

In looking for possible sites of block in maternal foetal transfer the maternal blood supply to the placenta was an obvious choice. The effect of restriction of utero-placental blood flow was investigated in the rat (Wigglesworth, I964). Ligation of the main uterine artery on one side was performed on the 17 th day of pregnancy so that the entire blood supply to the horn had to be derived from the ovarian artery; the animals were killed and examined 4 days later. Surviving foetuses within the ligated horn showed varying degrees of growth retardation, often with a complete gradation in size and with the smallest foetuses at the ischaemic end of the horn. Foetuses from control horns resembled those of intact control animals. There was little impairment in brain growth of stunted foetuses but considerable reduction in growth of their livers as seen typically in SFD babies. Histological study of the growth-retarded foetuses showed that organs matured as expected for gestation; chemical studies indicated low glycogen levels in heart and liver (Wigglesworth, 1968).

Experimental utero-placental ischaemia can, therefore, produce a similar picture to that seen in the growth-retarded baby, presumably due to limitation in nutrient supply to the foetus. This experimental model may well have its clinical counterpart in the babies of women with pre-eclampsia, a condition where reduced uteroplacental blood flow occurs in association with thrombotic occlusion of utero-placental arteries (Robertson, Brosens \& Dixon, 1967). The maximal rate of utero-placental blood flow which can be achieved for a particular uterus might also be an important factor in the normal maternal constraint of foetal growth towards the end of pregnancy.

Another possible site of block in foetal nutrition was indicated in experiments in which the hepatotoxic agent aflatoxin $B_{1}$ was given in a single dose to rats at various stages of pregnancy (Butler \& Wigglesworth, I 966). The drug had no effect on the foetuses if given early in pregnancy, but caused foetal growth retardation if given in late pregnancy. This effect seemed unlikely to be due to a direct action of aflatoxin on the foetus, as one would expect such an action to be more severe in early pregnancy. The severity of foetal growth retardation was however related to the extent of maternal liver damage, so that it seemed likely that the maternal liver was acting as a block to foetal nutrition in this experiment.

Biochemical studies on organs of rats malnourished at different times after birth (Winick \& Noble, 1966) have indicated that a nutritional stress applied during the phase of cell multiplication within organs may cause a deficit in cell population. A similar stress applied later, during the phase of cell growth within organs, causes a deficit in cell cytoplasm. With rehabilitation, the young animal can compensate for a reduction in cell size but is unable to make up a deficit in cell population.

If this concept can be applied to man in the prenatal period one can imagine that the effect on the foetus of any growth-retarding influence may be primarily dependent on the time course of its action, The two extremes would be the long thin 
malnourished-looking baby, who has been affected in the last few weeks of pregnancy only, and the short relatively well-proportioned baby with rubella syndrome whose growth was retarded in the first trimester. The long thin baby has a relatively normal number of thin cells whereas the rubella baby has a low cell population in organs throughout his body. These two situations are not, however, mutually exclusive so that a baby whose growth has been retarded for months rather than weeks may present some reduction in cell population in addition to a reduced cell size. In any individual case the infant's potential for physical and mental development is likely to be limited by the extent to which the cell population of different organs has been permanently depleted.

\section{REFERENCES}

Anderson, J. M., Milner, R. D. G. \& Strich, S. J. (1966), Lancet ii, 372.

Butler, N. R. (1965). In Gestational Age, Size and Maturity. Clin. Develop. Med. no. 19, p. 74. [M. J. R. Dawkins and W. G. MacGregor, editors.] London.

Butler, W. H. \& Wigglesworth, J. S. (1966). Br. F. exp. Path. 47, 242.

Dawkins M. J. R. (I964). Proc. R. Soc. Med. 57, ro63.

Eckstein P., Mckeown, T. \& Record, R. G. (1955). \%. Endocr. 12, 108.

Gruenwald, P. (1963). Biologia Neonat. 5, 215.

Hammond, J. (r96r). Ciba Fdn Symp.: Somatic Stability in the Nervly Born, p. 5. [G. E. W. Wolstenholme and M. O'Connor, editors.] London: Churchill.

McBurney, R. D. (1947). West. 7. Surg. Obstet. Gynec. 55, 363 .

McKeown, T. \& Record, R. G. (I953). F. Endocr. 9, $4 \mathrm{I} 8$.

McLaren, A. \& Michic, D. (1960). Nature, Lond, 187, 363.

Naeye, R. L. (1965a). Archs Path. 79, 284.

Naeye, R. L. (1965b). Am. \%. Path. 47, 905.

Robertson, W. B., Brosens, I. \& Dixon, H. G. (1967). 7. Path. Bact. 93, 58 I.

Robinson, R. J. \& Tizard, J. P. M. (I966). Br. med. Bull. 22, 49.

Schiff, D. (I968). PhD. Thesis, University of London.

Scott, K. E. \& Usher, R. (1964). New. Engl. F. Med. 270, 822.

Shelley, II. J. (1964). Br. med. F. i, 273.

Wigglesworth, J. S. (1964). Э. Path. Bact. 88, г.

Wigglesworth, J. S. (1968). In Aspects of Praematurity and Dysmaturity, Nutricia Symposium, p. I 19. [J. H. P. Jonxis, H. K. A. Visser and J. A. Troelstra, editors.] Leiden: H. E. Stenfert Kroese N.V.

Winick, M. \& Noblc, A. (I966). F. Nutr. 89, 300.

\section{The transmission of immune globulins from the mother to the foetal and newborn young}

\section{By F. W. Rogers Brambell, ARC Unit of Embryology, Department of Zoology, University College of North Wales, Bangor}

The young mammal or the young bird is equipped with a battery of antibodies derived from its mother that provide it with an effective but temporary immunity to disease, before it has learned to produce its own. At birth or hatching it has entered a world where it is beset with infections, from an environment where it was remarkably free from these and where, in consequence, it had little or no opportunity of developing specific resistance, even if its lymphoid system had reached a stage of 